\title{
A questão da laicidade no Brasil: mosaico de configurações e arena de controvérsias
}

\author{
The issue of secularism in Brazil: \\ mosaic of configurations and sand of controversies
}

\author{
Marcelo Ayres Camurça*
}

\begin{abstract}
Resumo
Este artigo visa apresentar as relações entre as religiões e o Estado no Brasil evitando um enquadramento teleológico e normativo, onde um modelo universal sirva de paradigma. Para tal, busca construir um mosaico de configurações diferenciadas que expressam situações de laicidade desiguais, mas convivendo entre si no país. Visa então, apresentar a própria noção de laicidade, tal como foi apropriada no Brasil, enquanto um processo que envolve conflitos, negociações e acordos em marchas e contra-marchas. Isto se dá através da interação de atores sociais, sejam eles quadros religiosos da Igreja Católica, evangélicos, pentecostais e das religiões afro-brasileiras, ou setores organizados da sociedade civil (feministas, LGBTs) e agentes estatais do sistema político e jurídico. As controvérsias em que estes atores sociais religiosos e laicos estão envolvidos abrangem um conjunto de temas, que vão desde aqueles que prefiguram uma retração da religião como descriminalização do aborto, união civil de homossexuais, inclusão dos direitos sexuais e reprodutivos no rol dos Direitos Humanos, até os que implicam na sua promoção como, o ensino religioso na escola pública e a presença de símbolos religiosos em repartições e fóruns estatais. Por fim, como não existe nenhuma definição normativa pré-existente do que seja laicidade, o que o texto postula é que, pelo caráter polissêmico que adquiriu no Brasil, esta noção é sempre invocada pelos segmentos em disputa - laicos e religiosos - de acordo com suas concepções e interesses próprios.
\end{abstract}

Palavras-chave: Religiões, Estado, laicidade, Brasil, controvérsias, mosaico

\begin{abstract}
This text aims to present the relations between religions and the State in Brazil avoiding a teleological and normative framework, where a universal model serves as a paradigm. To this end, it seeks to construct a mosaic of differentiated configurations between them that express situations of unequal secularity, but living together. It aims, then, to present the very notion of secularism, as it was appropriate in the country, as a process involving conflicts, negotiations and agreements in marches and counter-marches. This is done through the interaction of social actors, whether they are religious cadres of the Catholic Church, evangelicals and Pentecostals and AfroBrazilian religions, or organized civil society sectors (feminists, LGBTs) and state agents of the political and juridical system. The controversies in which these religious and lay social actors are involved cover a range of issues, ranging from those that foreshadow a retraction of religion such as: decriminalization of abortion, civil union of homosexuals, inclusion of sexual and reproductive rights in the role of Human Rights, to those that imply in their promotion as, the religious teaching in the public school and the presence of religious symbols in state offices and forums. Finally, since there is no pre-existing normative definition of what is secularity, what the text postulates is that because of the polysemic character it acquired in Brazil, this notion is always invoked by the disputed segments - secular and religious - according to their conceptions and interests.
\end{abstract}

Key words: Religions, State, secularism, Brazil, controversies, mosaic

Artigo submetido em 16 de janeiro de 2017 e aprovado em 23 de setembro de 2017.

*Doutor em Antropologia Social. Professor Titular nos Programas de Pós-Graduação em Ciência da Religião e Pós-Graduação em Ciências Sociais da Universidade Federal de Juiz de Fora (UFJF). Pesquisador e bolsista de produtividade PQ 02 do CNPQ. País de Origem: Brasil. E-mail: mcamurca@terra.com.br

Horizonte, Belo Horizonte, v. 15, n. 47, p. 855-886, jul./set. 2017 - ISSN 2175-5841 
Para Ronaldo de Almeida, sempre atento à questão da religião no espaço público. Para o babalorixá Ivanir dos Santos, na sua luta contra a intolerância religiosa.

\section{Introdução}

A partir da crítica à concepção teleológica e eurocêntrica da noção de secularização, e, por consequência, da de laicidade enquanto um modelo único, empreendida por José Casanova (1994) e TalalAsad (2003), em obras hoje já tornadas referências, abriu-se a perspectiva para enfoques mais plurais destes conceitos. Estes passaram a levar em conta contextos nacionais e civilizacionais, ritmos, trajetórias singulares pelos quais a relação entre religião, modernidade e esfera pública vem se estabelecendo.

Neste sentido, a perspectiva da comparação veio a se colocar no sentido de se pensar estilos distintos de laicidade(s), caminhos próprios de construção deste(s) regime(s), a partir dos diferentes pactos firmados entre as religiões e os Estados modernos em diversos recantos do globo. Vários autores, a partir daí, passaram então ao esforço comparativo, a começar pelo próprio Casanova, com o cotejo entre os casos da Espanha, Polônia, Brasil e Estados Unidos (1994); ou mesmo Asad, que, a despeito do seu estilo mais ensaístico e menos empírico, tratou dos casos dos muçulmanos na Europa e da lei e ética no Egito colonial (2003). Os franceses Philippe Portier e Jacqueline Lagrée organizaram um extenso compêndio intitulado "La modernité contre la religion? Pour une nouvelle approche de la laïcité", onde diversos autores se debruçaram sobre as vias nacionais de construção do pacto da laicidade nos Estados Unidos, na França, no Canadá, em Israel, na América Latina, na China e na Índia (2010). O próprio Portier já havia se dedicado à abordagem comparativa entre os "regimes de regulação do crer" nos países da Europa (2011) e entre os Estados Unidos e França (2010), e seu colega e compatriota, Jean-Paul Willaime empreendeu a comparação entre regimes de laicidade nos países da Europa (2011) e entre a França e a Alemanha (2010). 
No Brasil também assistimos os esforços comparativos de nossa situação em relação a outros modelos de regime de laicidade, como o texto de Ari Pedro Oro " $A$ laicidade no Brasil e no Ocidente: algumas considerações” (ORO, 2011, p. 221237), ou o artigo de Júlia Miranda, onde ela realiza uma comparação do Brasil com o Canadá (MIRANDA, 2013, p. 69-85); ou ainda o capítulo de Emerson Giumbelli no livro "Religión, cultura y política em las sociedades del siglo XXI", quando, ao discutir os termos "secularismo" e "laicidade", o autor procura o entendimento destas concepções na França, Uruguai, México e Brasil (GIUMBELLI, 2013a, p. 4368).

Foi dentro desta perspectiva, a de proporcionar uma comparação com outro enquadramento de laicidade, clássico e exterior ao Brasil, que este artigo foi construído. Apresentar um panorama do que se pode chamar os contornos de uma tipologia de "laicidade à brasileira" para o cotejo com outra configuração. Ele se realizou dentro do "IV Colóquio do Grupo de Pesquisa Religião e Cultura" intitulado "Religião e Contemporaneidade", em outubro de 2016, no Programa de Pós-Graduação em Ciências da Religião da PUC-Minas, particularmente na Mesa Redonda "Condições contemporâneas da Laicidade". Neste debate, buscou-se apresentar um painel - complexo e ambíguo - da situação brasileira em torno do regime de laicidade, para ser comparado com aquele que o Professor Philippe Portier apresentou para o paradigmático caso da França.

De fato, é na abordagem comparativa que se pode demonstrar a diversidade de formas pelas quais os Estados modernos se relacionaram com as religiões resultando em diferentes modos de regulação do religioso ou regimes de laicidade. Neste sentido, Cecilia Mariz, a partir de uma reflexão de David Martin, argumenta que se forjaram duas modalidades históricas diferenciadas do Estado regular o religioso: a da França, onde o Estado laico se constitui contra a religião (católica); e a dos EUA, onde o Estado laico se moldou a partir das religiões (MARIZ, 2011, p. 263-266). No primeiro caso, o Estado, na sua estratégia de autonomia, busca recalcar qualquer vestígio de religião no seu seio (diante do monopólio religioso 
exercido pela Igreja Católica numa situação anterior), e, no segundo caso, o Estado surge como uma instância autônoma das religiões, mas reconhecido por essas religiões, para defender a pluralidade religiosa contra o monopólio de uma sobre as demais, sendo ele mesmo, Estado, atravessado pelo discurso religioso cristão comum aos grupos religiosos que compõem a nação (MARIZ, 2011, p. 265). Philippe Portier, por sua vez, ao tratar da situação do regime da regulação do religioso no conjunto da Europa, num exercício comparativo, revela uma tendência crescente a um "movimento duplo". Nos países ditos confessionais - que adotam uma "religião de Estado" (Inglaterra, Dinamarca, Grécia), constata-se uma abertura na direção a um pluralismo religioso igualitário, ao passo que nos países de separação entre Igrejas e Estado (França, Alemanha, Espanha), verifica-se uma política crescente de reconhecimento do papel das religiões no domínio público (MARIZ, 2011, p. 11-23). Ricardo Mariano, fundamentado também numa análise comparativa, considera o quadro brasileiro como uma "quase laicidade" numa analogia com a mesma afirmação do cientista político português Fernando Catroga para os países católicos europeus, Portugal, Espanha e Itália (CATROGA, 2006 apud MARIANO, 2011, p. 254).

Esta breve menção a situações de comparação já aponta para uma dimensão mais plural e nuançada da laicidade do que uma pretensa condição de plena autonomia e preeminência do Estado em relação às religiões como modelo ideal a ser seguido, sob pena de uma maior e mais ativa presença religiosa na esfera pública ser classificada como uma descaracterização do modelo. Este modelo, então, tende a reduzir a análise da laicidade a um esquema bipolar, como se sua dinâmica em um país ou região se resumisse, de um lado, em iniciativas de implementação de atos de soberania e neutralidade do Estado em relação às religiões existentes, e, de outro, de iniciativas de confessionalização da esfera pública por religiões ultrapassando os limites da normatividade republicana do "bem comum". 
No sentido de ultrapassar este esquema reducionista, sigo aqui a sugestão de Giumbelli de tomar esses parâmetros de laicidade não como "modelos" e "princípios" com força normativa, mas, ao contrário, examinar "como" eles funcionam e se constituem (GIUMBELLI, 2013a, p. 51-54). Isto se dá através de um acompanhamento das formas e canais nos quais se efetivam as relações entre agentes religiosos (em suas especificidades) e espaços sociais (historicamente constituídos em conjunturas específicas) (GIUMBELLI, 2013a, p. 56).

No caso do Brasil, a sugestão poderia ser a de buscar detectar suas especificidades no que diz respeito à relação das religiões e o Estado através de situações concretas de interação e fricção envolvendo religiões e instâncias públicas e laicas. Ou seja, examinar em situação contextual os diversos discursos e ações sobre o lugar do religioso no espaço público. Discursos e ações estas provenientes de distintos atores e agentes sociais ditos laicos (como juristas, feministas, homossexuais, gestores públicos etc) e religiosos (católicos, evangélicos, afrobrasileiros, new agers, ecumênicos) numa perspectiva "oposta" e até "excludente" de uns em relação aos outros; mas também suas possibilidades de negociação, acordos e alianças e as resultantes/consensos possíveis dos embates em termos de normas e de comportamento social sobre o lugar da religião no espaço público.

\section{Um mosaico de configurações de laicidade no Brasil}

Para se refletir sobre a questão da laicidade hoje precisa-se de um novo olhar. Ao invés de um modelo abstrato e normativo de laicidade, através do qual as situações concretas são avaliadas positivamente ou negativamente por aproximação ou distanciamento deste, a alternativa será a de buscar o "ponto de vista nativo" do que é considerado laicidade pelos próprios agentes (religiosos e laicos) em tela. Ao invés do que a laicidade deve ser segundo paradigmas jurídicos, constitucionais e programáticos, deve-se contemplar como os atores sociais contextualizados se apropriam destas normas consagradas como "regime laico" em função dos seus interesses e projetos. 
Este artigo propõe, à maneira antropológica, oferecer não uma resolução sobre o que é "normativamente correto" para o país, no que tange à questão da laicidade, mas um mosaico de distintos cenários onde pontos de vista diversos se expressam. Faço isto na tentativa de alcançar um quadro mais complexo, ainda que multifacetado e desigual, algo como uma colcha de retalhos. A questão que fica é a de como articular estes cenários diferenciados em busca de algum regime de comensurabilidade entre eles.

Longe de ser um processo unilateral e unívoco, a relação entre Estado, esfera pública e as religiões no Brasil comporta tanto iniciativas de forças laicistas no sentido de reverter presenças religiosas no Estado consolidadas ao longo dos anos, quanto de novas ações provenientes das religiões de se apropriar de espaços ainda não ocupados no domínio público, ambos ao mesmo tempo e de forma contraditória. Além destes dois movimentos opostos, podemos ainda assistir outros, que replicam a mesma clivagem entre relações de força de expansão e retração da religião no espaço público. De um lado, ações de determinadas religiões no campo moral, através de instrumentos do Estado no sentido de frear e coibir intervenções de agentes estatais promovidas enquanto políticas públicas ou sanitárias; e, de outro lado, a intervenção do Estado e agentes públicos aliados com religiões minoritárias no sentido de salvaguardar a liberdade de existência destas diante da intolerância de outras religiões majoritárias.

Portanto, na busca de capturar, pelo menos em parte, este complexo, assimétrico e contraditório quadro, gostaria de apresentar quatro cenários que, a meu ver, expressam espaços onde diversos atores sociais (laicos e religiosos) investem discursos, dispositivos legais, midiáticos, políticos para estabelecer uma configuração do que compreendem como o lugar do religioso no espaço público, ou do que seja um regime de laicidade.

Para construir um esquema de compreensão do que poderia ser um quadro da laicidade no Brasil, devido ao seu caráter contraditório e fluido, me inspirei e me apropriei, ainda que de forma livre, de três noções. De Philippe Portier, incorporei 
a expressão "mosaico" que ele emprega em um prefácio ao livro "Le mouvement catholique français à l'épreuve de la pluralité” (PORTIER, 2002), para explicitar o caráter multifacetado do catolicismo francês, fragmentado entre a hierarquia eclesiástica, a subjetivação e comunitarização dos fiéis "que, a despeito de uma tradição partilhada, se ignoram uns em relação aos outros" (PORTIER, 2002, p. 15). De Emerson Giumbelli, a noção de "configuração" a que ele recorre, entre outras, para compor um esboço de um plano de estudos sobre a "regulação do religioso" no Brasil. Para este autor, "formas de configuração da diversidade religiosa” (GIUMBELLI, 2013a, p. 63) são produtos das posições assumidas pelos atores sociais (religiosos e laicos) em disputa, que se materializam nos "arranjos políticos", assumindo "formas variáveis e heteróclitas", de acordo com a situação e o peso das forças em confronto (GIUMBELLI, 2013a, p. 48). E, por fim, dos autores Eade e Sallnow, a ideia da "arena”, forma pela qual estes viram o fenômeno das peregrinações religiosas enquanto lugares onde se confrontam de forma simultânea discursos religiosos e laicos, hierarquias religiosas e religiosidades populares a partir de uma mesma tradição e pertença num sentido alargado ao catolicismo (EADE; SALLNOW, 1991, p. 5-10).

A articulação que empreendo a partir destas três noções - produzidas para fins diferentes - está relacionada ao fato de que nelas está presente a tensão entre diversidade e campo comum. "Arena", "mosaico" e "configuração" passam a ideia de formas onde convivem as diferenças em acomodação ou conflito e a referência a uma "tradição comum, partilhada" revela também que todas as diferenças reivindicam uma pertença dentro de um locus comum, no meu caso, a laicidade.

Com tal esquema desenhado, passo a apresentar em seguida, estes quatro cenários ou configurações de laicidade no Brasil que compõem um conjunto não inteiriço, e sim, um mosaico. As configurações deste mosaico vão em direções diferentes, mas em par, as duas primeiras:

a) ações religiosas no campo da moral inibindo iniciativas de defesa de direitos de minorias e direitos humanos; 
b) entronizações de símbolos religiosos em ambientes laicos e públicos, onde ambas implicam em movimentos de expansão da religião no espaço público; e as duas seguintes;

c) ações para retirada de símbolos religiosos na esfera pública;

d) ações jurídico-legais contra a intolerância e vilipêndio religioso, que redundam em movimentos de contenção desta expansão religiosa através de legislação e marcos legais. Acrescento ainda que cada uma destas configurações do mosaico são, em si mesmas, arenas que contém internamente embates e controvérsias entre atores religiosos e laicos em disputa pelo formato final de cada configuração. A resultante destes jogos de força pode ser tanto de acordos quanto de imposições, relacionados com a correlação das forças em jogo.

\section{Cenários de expansão da religião no espaço público}

\subsection{Ações religiosas no campo da moral inibindo iniciativas laicas de defesa de minorias de direitos humanos}

Desde a Constituinte de 1988, evangélicos pentecostais decidiram investir contra iniciativas protagonizadas por setores laicos no cenário jurídico-político que buscavam expandir uma agenda em torno dos direitos humanos e cidadania (MARIANO, 2011, p. 251-252).

Como protagonistas destas ações estavam grupos que reuniam feministas, homossexuais, intelectuais, jornalistas, educadores, juristas, artistas, gestores estatais articulados para o estabelecimento de políticas públicas referentes à saúde, educação, pesquisas científicas e ordenamento jurídico legal que assegurasse às minorias direitos humanos, sexuais e reprodutivos, sem interferência religiosa nestas políticas (MARIANO, 2011, p. 252).

Desta forma, tanto do lado dos proponentes desta agenda laica quanto dos religiosos que, por razão de credo e moral, tendiam a se antagonizar à nova agenda, 
pouco a pouco se estabeleceu uma pauta de temas para ser aprovada ou rejeitada que gerou intenso debate no parlamento, no governo e na sociedade. Este debate se fez presente em projetos de lei e em medidas governamentais como o $3^{\mathrm{o}}$ Plano Nacional de Direitos Humanos de 2010, e versou sobre as seguintes questões: descriminalização do aborto, união civil homossexual, criminalização da homofobia, adoção de crianças por pais homossexuais, inclusão de direitos sexuais reprodutivos no rol dos direitos humanos, políticas educacionais de distribuição em escolas públicas de material informativo sobre a sexualidade, como prevenção contra a homofobia, regulamentação das funções de profissionais do sexo, ensino laico sem interferência religiosa, pesquisas científicas com células-tronco (ORO; MARIANO, 2010, p 25,27; MARIANO, 2011, p. 251-253; MIRANDA, 2013, p. 71).

Embora movidos por sua visão conservadora, contra o que consideravam uma desagregação da moral e dos bons costumes na sociedade brasileira, se esses projetos fossem aprovados as forças religiosas capitaneadas por evangélicos pentecostais, mas também pela Igreja Católica e em alguns casos por outras religiões neo-cristãs, como o Espiritismo Kardecista, manteriam suas ações dentro dos expedientes jurídico-políticos do arcabouço republicano para fazer valer suas propostas de desarticular as iniciativas das forças laicas. No caso do projeto de lei que visava criminalizar a homofobia, a argumentação das forças religiosas no parlamento era que esse projeto restringia a liberdade religiosa e a liberdade de opinião, direitos inalienáveis da cidadania, pois através dele poder-se-ia incriminar indivíduos apenas por possuírem concepções de fundo religioso discordantes da homossexualidade.

À maneira dos movimentos organizados da sociedade civil, as forças religiosas católicas e evangélicas conservadoras se articularam contra os projetos de descriminalização do aborto e união civil homossexual, às vezes alargando para outros grupos religiosos, como no caso da criação do "Movimento Nacional Cidadão pela Vida - Brasil sem Aborto” que contou com o apoio da CNBB, Frente 
de Deputados Evangélicos e Federação Espírita Brasileira (MIRANDA, 2013, p. 71). ${ }^{1}$

Na sua oposição aos grandes projetos de fundo dos grupos laicos, a frente católico-evangélica conseguiu impor um recuo considerável no que os primeiros propuseram como diretrizes de políticas públicas no país. Exemplos disto foram a retirada da matéria sobre a descriminalização do aborto do $\mathrm{PNH}_{3}$ pelo Governo Lula (MARIANO; ORO, 2010, p. 25), a também retirada da campanha encetada pelo Ministério da Educação nas escolas públicas sobre o reconhecimento da diversidade sexual, o estigmatizado "kit-gay", e, por fim, o recuo da pauta dos direitos humanos, sexuais e reprodutivos pela campanha presidencial de Dilma Roussef com o compromisso firmado com a bancada evangélica "de assegurar a liberdade religiosa, de vetar qualquer projeto [...] 'contra a vida e os valores da família', de rejeitar o casamento homossexual, o projeto de lei que criminaliza a homofobia” (MARIANO; ORO, 2010, p. 30).

A consciência da representatividade de suas concepções religiosasconservadoras no seio da população e na "cultura" nacional - lembrar que a soma dos $64,6 \%$ de adeptos do catolicismo com os 22,2\% de evangélicos perfaz, segundo o Censo de 2010, o total de $86,8 \%$ da população brasileira) - explica a postura arrojada deste bloco religioso para a consecução de suas propostas de configuração do Estado em relação aos valores religiosos, ou seja, sua concepção de como funciona e o que é o dispositivo e arranjo da laicidade no país. Neste sentido é que se pode entender a afirmação de altos dirigentes da Igreja Católica e de porta vozes de seus movimentos mais pujantes, como os carismáticos, de que "O Estado é laico, mas não é ateu!" (MIRANDA, 2013, p. 70; ORO; MARIANO, 2010, p. 35). Por isso também, a constatação do sociólogo Ricardo Mariano de que “a laicidade estatal no

\footnotetext{
${ }^{1}$ No entanto, ocorreu também uma certa flexibilização neste conservadorismo, quando algumas forças religiosas adotam uma postura mais liberal no campo da moral. Por exemplo, a neopenteocostal Igreja Universal do Reino de Deus se posicionou a favor do "planejamento familiar" e do uso de preservativos contra doenças sexualmente transmissíveis; assim como na admissão do aborto em contexto de estupro e de anomalia fetal, distinguindo-se da Igreja Católica nestes casos (MACHADO; MARIZ, 1998, p. 18-19). A Igreja Católica também ficou isolada em relação às demais religiões (cristãs) na sua posição contra pesquisas com células-tronco quando de sua votação e aprovação pelo STF.
} 
Brasil não [...] dispõe de força normativa e ascendência cultural para promover a secularização da sociedade", de modo que "tem sido acuada pelo avanço de grupos católicos e evangélicos politicamente organizados e mobilizados para intervir na esfera pública” (MARIANO, 2011, p. 254). Da mesma forma, Giumbelli afirma que a "laicização generalizada" pode ser uma "aspiração ou projeto", mas que "não ganha tradução em políticas concretas e abrangentes” (GIUMBELLI, 2012, p. 47). Acrescento eu, que este "avanço religioso" não se dá de forma extra-laica, mas sim utilizando a mediação do modelo estatal, laico, republicano (partidos, lobbies, petições, atos públicos, aprovações de leis nos parlamentos e tribunais).

\subsection{Entronização de símbolos religiosos em ambientes laicos e públicos}

Existe uma presença histórica e naturalizada de crucifixos em escolas, universidades, tribunais e parlamentos testemunhando centenas de anos de presença católica no aparelho estatal. Além disso, assiste-se na atualidade o recrudescimento da entronização de novos símbolos religiosos no espaço público. Particularmente, por iniciativa de segmentos evangélico-pentecostais o erguimento de monumentos à Bíblia e aposição de Bíblias em escolas públicas, hospitais e parlamentos (RANQUETAT JR, 2012, p. 62).

O início deste movimento foi uma emenda do deputado evangélico Antonio de Jesus, de Goiás, aprovada na Assembléia Constituinte de 1988, para a exibição da Bíblia na Mesa diretora desta Assembléia, expediente depois incorporado perenemente no Regimento Interno da Câmara Federal (RANQUETAT JR, 2012, p. 7-71). A partir daí, esta iniciativa espraiou-se para várias Assembléias Legislativas e Câmara Municipais do país, inclusive fazendo parte, por dispositivo regimental, a leitura de trechos da Bíblia no início das sessões parlamentares, com a Câmara Federal não fugindo à regra, a partir de 1999 (RANQUETAT JR, 2012, p. 72). Além disto, por iniciativa pioneira do mesmo deputado federal Antonio de Jesus em 1987, o governo de Brasília destinou espaço para construção do $1^{\circ}$ monumento à 
Bíblia, e a esta construção seguiram-se outras por todo o país: Bahia, Santa Catarina, Amapá, Rio Grande do Norte e São Paulo.

A justificativa evangélica para tal apropriação do espaço público pelo religioso obedeceu ao mesmo argumento já apresentado pelos católicos anteriormente, onde crucifixo e Bíblia são reivindicados como símbolos de caráter universal, inspiradores de valores profundos da humanidade, independente de crençasreligiosas (RANQUETAT JR, 2012, p. 71). Aquium argumento que não parece submeter ostensivamente ao regime laico, mas propor uma acomodação com ele: defender a promoção de uma nítida imagem religiosa, mas com um argumento de que esta representa valores para além das religiões.

Esta convergência católico-evangélica para a aposição de símbolos religiosos no espaço público nutre-se da ideia de que valores espirituais devem se constituir como reserva moral da nação. E aqui, segundo Ranquetat Jr, o argumento toma um "víeis culturalista”, ou seja, de procurar relacionar o fundamento da nação brasileira ao cristianismo (RANQUETAT JR, 2012, p. 63). Este caso particular poderia sugerir para o caso brasileiro a ideia de "Religião Civil", que Robert Bellah aplicou aos EUA (BELLAH, 1987, p. 169-189). Ou seja, uma meta-religião acima de todas as religiões existentes e com concordância destas, a partir de símbolos cristãos representando toda a nação. Mas aqui teríamos um problema, pois estes símbolos, a despeito de sua justificativa de universalidade (e da representatividade do cristianismo no país, cobrindo mais de $86 \%$ das crenças e pertenças de seus habitantes), na verdade estão sendo utilizados numa competição religiosa entre católicos e evangélicos para fazer sua inscrição particular na esfera pública, mais que representar o conjunto da nação de forma religiosa. Ranquetat Jr indica que o conjunto de ações dos evangélicos de exposição da Bíblia nas praças e recintos estatais obedece a uma estratégia de reação ao território tradicionalmente já conquistado pela Igreja Católica no aparato do Estado brasileiro (RANQUETAT JR, 2012, p. 77). E Ricardo Mariano sublinha que “a concorrência entre católicos e 
evangélicos migrou [do campo religioso específico] para as esferas midiática e política" (grifo meu) (MARIANO, 2011, p. 249).

Neste sentido, Ranquetat $\mathrm{Jr}$ apresenta algumas distinções entre os dois símbolos e suas utilizações. A presença dos crucifixos "católicos" não se dá por dispositivo administrativo e nem é objeto de culto e devoção, seguindo numa "invisibilidade" da qual já chamou atenção Giumbelli (2012); por sua vez, a entronização da Bíblia nas praças e parlamentos aconteceu por dispositivos regimentais- apesar de justificada como inspiradora de valores morais de fundo não assumindo sua faceta de proselitismo religioso -, apropriando estes logradouros como espaço de celebrações, batismos e festividades, ou seja, como demonstração pública de poder por evangélicos (RANQUETAT JR, 2012, p. 76). O fato de um símbolo poder ser objeto de culto e invocação (a Bíblia) e o outro (o crucifixo) restar quase que "invisível”, funcionando, em última instância, como inspiração moral, serve para demonstrar o papel mais proativo dos evangélicos na cena pública em relação ao do catolicismo, declinante.

No entanto, também do lado do catolicismo, assistimos a colocação de novos símbolos em logradouros públicos, expandindo os tradicionais lugares religiosos já cativos deste mesmo catolicismo. Esta ação ocorre no Nordeste, reduto populacional da Igreja Católica, particularmente no Ceará, segundo estado mais católico do país, funcionando como uma nova estratégia de reação católica provinda da hierarquia da Igreja e articulada ao movimento carismático para tentar conter a expansão evangélica. A pesquisa de Miranda resenha o que ela chama de "reavivamento do catolicismo" através de um movimento de "dessecularização" das praças públicas da capital Fortaleza e de sua região metropolitana com a ereção de 11 imagens sacras, sendo 5 da Virgem Maria, configurando-se aí, nas palavras da autora, uma nova "cartografia da fé" (MIRANDA, 2013, p. 75). Convém lembrar que o culto mariano e a obediência ao Papa foram apontados como os dois marcos diacríticos pelos quais o movimento carismático católico busca se diferenciar e competir com os evangélico-pentecostais (ORO, 1996). 
Esta gradativa conquista de espaço nas praças para fins religiosos tem gerado protestos de outros segmentos da população na grande imprensa, que se sentem tolhidos no seu direito de usufruir o espaço. Além disto, reclamam do “aspecto estético" de "gosto duvidoso" das imagens (MIRANDA, 2013, p. 84, nota 21). Aqui uma diferença em relação ao colosso do Cristo Redentor do Rio de Janeiro, que foi inaugurado na década de 1930 com nítidas intenções de marcar o hegemonismo religioso católico, mas que, segundo Giumbelli, por suas características de vanguarda artística (art déco), teria sido paulatinamente assimilado como um símbolo da cidade inteira (GIUMBELLI, 2012, p. 48-49). No entanto, na mesma direção do que se passa no Ceará, (talvez sem a mesma eficácia simbólica deste, pelo fato do Rio ser a região mais secularizada e menos católica do país), Giumbelli também aponta iniciativas da hierarquia da Igreja e do seu clero de "incremento de atividades católicas em torno do monumento", "recentemente reconhecido como "santuário", quando as autoridades católicas reclamam o “sentido religioso" da imagem do Cristo (GIUMBELLI, 2012, p. 51).

Ao lado destas manifestações na imprensa, Miranda registra também inúmeros debates surgidos na Assembléia e Câmara Municipal deflagrados por “evangélicos e ateus”, que, invocando a condição laica do Estado brasileiro, protestam contra a ocupação indevida pelos católicos dos logradouros públicos (MIRANDA, 2013, p. 84, nota 20). Aqui, da mesma forma que no caso da votação da "Lei Geral das Religiões" como alternativa e complementação ao "Acordo do Brasil-Vaticano" e também da colocação de Bíblias em parlamentos e estabelecimentos públicos em contraposição à presença dos centenários crucifixos, nota-se a invocação por evangélicos - num primeiro momento aliados a setores laicos -, do princípio de laicidade contra os "privilégios" concedidos à Igreja Católica, para, em seguida, conceber a laicidade como uma expressão do religiosomais equilibrada entre católicos e evangélicos no cenário público. Uma prova disto, ainda na pesquisa de Miranda, foi a iniciativa do Presidente da Câmara de Vereadores de Fortaleza, o católico carismático Walter Cavalcante, de incluir celebrações religiosas na programação da emissora da Câmara (rádio e TV), 
começando com a exibição de missas, para, em seguida, flexibilizar a programação com a inclusão dos cultos evangélicos (MIRANDA, 2013, p. 85, nota 31).

Outra forma de retomada da presença religiosa na esfera pública que reproduz esta proporcionalidade católico-evangélica é a do Ensino Religioso, pelo menos no formato que tomou no Rio de Janeiro. O modelo do Rio de Janeiro estabeleceu a "forma confessional" de Ensino Religioso, tendo professores e conteúdos curriculares de acordo com cada confissão religiosa particular, numa equivalência de cerca de 50\% de católicos, $40 \%$ de evangélicos e $10 \%$ de outras confissões (GIUMBELLI, 2004, p. 53). Segundo Giumbelli, o modelo do Rio de Janeiro manteve a continuidade com uma situação histórica onde o Ensino Religioso sempre esteve vinculado à influência da Igreja Católica no Estado (GIUMBELLI, 2004, p. 53 e 58). Porém, agora se estabelece uma diferença, pois há um compartilhamento prioritário com o credo evangélico (havendo um espaço diminuto, muitas vezes não ocupado, pelas demais religiões), na forma de uma laicidade concebida como pluralidade religiosa no espaço público, melhor dizendo, pluralidade cristã sob a forma hegemônica católico-evangélica.

Em outro texto, o mesmo autor traz à tona uma experiência de fato pluralista de ocupação pública por símbolos religiosos que são os Espaços InterReligiosos em hospitais, aeroportos e Shopping Centers (GIUMBELLI, 2013b). Esta experiência vem ocorrendo na cidade de Porto Alegre e se manifesta em iniciativas como a do Espaço Inter Religioso do Aeroporto Salgado Filho, inaugurado em 2002 por solicitação da Empresa Brasileira de Infraestrutura Aeroportuária. Ele consiste num espaço comum com nichos destinados às religiões católica, muçulmana, judaica, evangélicos, luteranos, afro-brasileiras, anglicana, budista e hinduísta (GIUMBELLI, 2013b, p. 42). Da mesma forma, o Espaço Ecumênico do Shopping Barra Sul, sem símbolos religiosos, tendo uma parede branca com a palavra "paz" em 10 idiomas (GIUMBELLI, 2013b, p. 42). E por fim, os Espaços Inter Religiosos dos hospitais particulares Têmina (GIUMBELLI, 2013b, p. 43). Todos esses lugares 
são geridos pelo Fórum Inter Religioso da cidade que reúne representantes de religiões com presença em Porto Alegre. O Fórum tem por objetivo "apostar nos efeitos de visibilidade [...] de diversas religiões em celebrações conjuntas" [...] com finalidade de prestar assistência espiritual e litúrgica celebrativa em eventos oficiais e não oficiais" (GIUMBELLI, 2013b, p. 41). Então, nestas experiências pioneiras desenvolvidas na cidade de Porto Alegre parece que assistimos uma tendência de "descatolicização" do espaço público, em prol de uma concepção de diversidade religiosa (GIUMBELLI, 2013b, p. 43).

Por fim, resta o registro de uma manifestação pública de imagem religiosa, neste caso, liderada pelas religiões afro-brasileiras. Estou me referindo às "Caminhadas em Defesa da Liberdade Religiosa” realizadas a partir de 2008 na orla marítima de Copacabana, em resposta à violência sofrida por terreiros, centros, ialorixás, babalorixás e o "povo de santo", por parte de religiões neopentecostais (ORO, 2011, p. 229; MIRANDA, 2010, p. 132). Também figura neste contexto a "Caminhada dos Terreiros de Pernambuco", um ato público e político que percorre as ruas do Recife antigo protestando contra a intolerância religiosa, o preconceito contra o povo de santo e o racismo. Este ato existe desde 1997 quando tinha o nome de "Caminhada contra Discriminação Religiosa e o Racismo", tendo se iniciado com o projeto de construção do Memorial Águas de Iemanjá, concluído em 2007 na praia do Pina em Recife (RODRIGUES, 2014, p. 127-128). A $5^{\text {a }}$ Caminhada em 2011 contou com a presença do prefeito da capital e de representantes da Secretaria Estadual de Educação e do setor de Igualdade Racial da Secretaria de Direitos Humanos da Prefeitura, e se reivindica como um ato de cunho político-religioso que reúne todos os terreiros de Candomblé e Jurema do Recife, onde o povo de santo sai às ruas vestido com roupas rituais e entoam seus cânticos como se fosse um grande xiré (ritual festivo) público (RODRIGUES, 2014, p. 129-130). No panfleto que circulou na "Caminhada", assinado pela organização do evento, há a menção à garantia da "liberdade de crença e credo" pelo "estado de Direito assegurado na Constituição de 1988" ameaçado pela ação de "grupos e representantes proselitistas, oportunistas e radicais" que atuam no âmbito estadual 
e municipal” (RODRIGUES, 2014, p. 131), numa clara referência à bancada evangélica e às ações de intolerância religiosa provindas dos neopentecostais.

Outra afirmação pública de um símbolo religioso proveniente das religiões afro-brasileiras foi a que ocorreu com o soerguimento de um monumento com 07 estátuas dos orixás no Dique do Itororó em 1998, na cidade Salvador (BA). Contudo, como afirma Sansi, esta iniciativa não partiu das próprias religiões afrobaianas, mas do poder público enquanto uma obra de arte visando embelezar a cidade. Neste particular, buscou-se destacar um dos símbolos marcantes da cultura da Bahia: os orixás (SANSI, 2005, p. 64-65). Isto gerou manifestações de desaprovação e protesto capitaneadas pela igreja neopentecostal Universal do Reino de Deus (IURD), indo de atos públicos até ações de iconoclastia. Toda a controvérsia surgida suscitou a intervenção do então governador do Estado Antônio Carlos Magalhães para assegurar a obra; assim como o recuo da IURD devido à correlação de forças desfavorável - que reconheceu seu "erro" ao considerar imagens diabólicas o que foi afirmado pelas autoridades máximas do Estado como simplesmente obras de arte (SANSI, 2005, p. 70). Segundo o autor desta pesquisa, não houve registro de participação dos terreiros e Casas de Santo na ereção do monumento, até porque a representação de imagens dos orixás não tem centralidade na prática religiosa do Candomblé em relação às “otans” (pedras) e os "assentos" para os sacrifícios e oferendas aos deuses (SANSI, 2005, p. 66). Ao contrário das imagens dos santos católicos, onde o que prevalece é a sua publicização, a relação com os orixás segue a lógica da ocultação, dos segredos iniciáticos (SANSI, 2005, p. 66-67).

Diferentemente dos “monumentos à Bíblia" evangélicos, apontados anteriormente, um provável culto a estas imagens é controlado pelas autoridades municipais, sendo vedados sacrifícios “de sangue” diante da obra - lembro que antes o Dique era lugar tradicional de oferendas a Oxum, orixá da água doce (SANSI, 2005, p. 64). Aqueles que quiserem fazer uma oferenda, um “ebó”, segundo as autoridades, só podem trazer flores e frutas, mas não animais mortos, 
que poluem e cheiram mal (SANSI, 2005, p. 75). Afinal, trata-se de um conjunto de objetos de arte que apenas evocam e representam a presença do Candomblé na cultura da cidade - não deixando de ser um prestígio conferido a esta religião - mas não um espaço de culto propriamente dito. Por fim, o autor fala que pouco a pouco as estátuas passam a ser incorporadas à paisagem, como um pano de fundo desta, semelhantes a outros monumentos que povoam o ambiente público das cidades (SANSI, 2005, p. 77). Estaríamos assistindo no caso, àquela apropriação cultural e laica a que foi submetida o símbolo religioso do Cristo Redentor no Rio de Janeiro? (GIUMBELLI, 2012) ou estariam os orixás caindo na "invisibilidade" dos crucifixos católicos nos tribunais e recintos estatais? (GIUMBELLI, 2012).

\section{Cenários de contenção das religiões no espaço público}

\subsection{Ações para retirada de símbolos religiosos no espaço público}

Desde meados dos anos 2000 por reflexo de uma interpretação da Constituição Federal de 1988, particularmente do seu artigo 19, inciso I, assiste-se um conjunto de medidas judiciais para a retirada de crucifixos de recintos públicos - Tribunais e Casas Legislativas. A alegação, na interpretação do referido artigo, recorrente em todas estas demandas, é de que a manutenção destes símbolos fere o princípio de laicidade, de separação da Igreja e do Estado, levando que servidores alocados nestes recintos terminem por se submeter a outros princípios (religiosos) que não os da administração pública (RANQUETAT JR, 2012, p. 67-68). Podemos citar, entre outras iniciativas, a moção do Juiz Lorea no $6^{\circ}$ Congresso dos Magistrados solicitando a retirada dos crucifixos da sala de audiência dos Tribunais (RANQUETAT JR, 2012, p. 65), quatro pedidos ao Conselho Nacional de Justiça provenientes da "Associação de Ateus e Agnósticos” para retirada destes símbolos sacros das salas dos tribunais de diversos estados da federação (Ceará, Minas Gerais, Santa Catarina e do TRF $4^{\mathrm{a}}$ região) (RANQUETAT JR, 2012, p. 67) e uma cláusula no Plano Nacional de Direitos Humanos ( $\mathrm{PNH} 3$ ) de 2009, que indica a 
não ostentação de símbolos religiosos em estabelecimentos públicos da União (GIUMBELLI, 2012, p. 43).

A quase totalidade destas demandas não prosperou, sendo rejeitadas nas instâncias competentes (e no caso do PNH 3, o Governo Federal em 2010 editou novo decreto retirando esta cláusula do texto), salvo uma que foi acolhida na instância máxima do poder judiciário do Rio Grande do Sul que emitiu decisão para a retirada dos símbolos de suas dependências (GIUMBELLI, 2012, p. 46). A justificativa oferecida pelas instâncias decisórias para a manutenção dos símbolos foi a de que a imagem do Cristo martirizado é um símbolo universal, para além de aspectos confessionais e particularistas, neste sentido fazendo parte do patrimônio público (RANQUETAT JR, 2012, p. 64-65). E o cristianismo funcionando como uma religião natural, fonte básica de direitos e normas morais (RANQUETAT JR, 2012, p. 67). Segundo a pesquisa de Ranquetat Jr, por um lado esta argumentação não invoca uma ideia explícita da submissão do poder civil ao poder religioso, mas sim um aspecto de compromisso com a noção da separação dos poderes e autonomia republicana (defendendo os símbolos religiosos mais pela sua evocação universalista e moral); por outro, o argumento respalda-se na ideia do costume, tradição histórica que vincula o país a uma “cultura católica brasileira” (RANQUETAT JR, 2012, p. 69). Isto, no entender do autor, como forma de se preservar dos questionamentos de "evangélicos e atores secularistas" em contexto de expansão de suas ações contra o que atribuem serem os privilégios centenários da Igreja Católica (RANQUETAT JR, 2012, p. 69; ORO, 2011, p. 229, 235). No caso dos evangélicos, note-se as reclamações históricas contra tratamento desigual do Estado à Igreja Católica, particularmente no que tange ao feriado nacional de 12 de outubro consagrado à padroeira do Brasil e ao caso das capelanias militares com vantagens concedidas aos católicos (RANQUETAT JR, 2012, p. 77).

Interessante que esta conjunção de interesses (momentânea) entre evangélicos e laicos contra indicadores de hegemonia católica no aparato estatal vai 
se espraiar para outros domínios da vida pública como foi o caso do Acordo firmado em 2008 pelo governo Lula e o Vaticano. Através deste acordo estabeleciase garantias fiscais, proteção de lugares de culto e do patrimônio histórico cultural de bens da Igreja, destinação de espaços públicos a fins religiosos, capelanias em hospitais e presídios, ensino religioso em escolas públicas e efeitos civis do casamento religioso (RANQUETAT JR, 2010, p. 176). Este acordo ecoou no Congresso Nacional de forma bombástica e produziu uma reação de parlamentares laicos e evangélicos contra o que chamaram de atentado contra a laicidade do Estado e a isonomia e liberdade religiosa, ao oferecer privilégios a apenas uma religião (RANQUETAT JR, 2010, p. 179, 181). De toda essa polêmica resultou a "Lei Geral das Religiões" costurada pela força da bancada evangélica no Congresso com o apoio dos demais setores (e aquiescência das forças católicas) que estendia as mesmas cláusulas da concordata com a Igreja Católica para todos os credos. Em tempo recorde foram votadas e aprovadas pelo Legislativo nacional as duas leis com apenas o voto contrário da bancada do PSOL, que considerou ambas as leis como atentatórias ao regime de separação Igreja-Estado (RANQUETAT JR, 2010, p. 179,181). A conseqüência de toda esta polêmica pública foi a extensão do reconhecimento em termos de presença pública conquistada pela religião católica às demais, leia-se aos evangélicos - e não a supressão desta presença para toda $\mathrm{e}$ qualquer religião como desejavam os setores laicos - fórmula que se alargará para outros eventos. Nestes, cada vez mais a concepção de laicidade imperante no país passa a ser de uma presença isonômica das religiões (mais representativas, as cristãs, ou seja, católicos e evangélicos) no domínio público.

Outro affaire que implicou em proposições de retirada de símbolos religiosos de espaços públicos, descrito etnograficamente por Emerson Giumbelli, envolveu a "capela católica” do Hospital das Clínicas da Porto Alegre (GIUMBELLI, 2013b, p. 32-47). Aqui o alvo foi novamente a Igreja Católica e a argumentação contrária visava as relações privilegiadas desta com o Estado, estabelecidas tradicionalmente. Sob nova direção, o Hospital das Clínicas de Porto Alegre decide não renovar com a Igreja Católica o contrato de pagamento a serviços de 
assistência religiosa que se dava no espaço de uma capela e solicita a desocupação deste espaço para sua utilização como "espaço de espiritualidades” (GIUMBELLI, 2013b, p. 34). Com base no artigo 19 da Constituição que evoca o princípio da laicidade, a proposta seria de transformação do lugar em um espaço neutro, sem referência religiosa, visando o "recolhimento espiritual” e a contemplação, sem existência de cultos ou celebrações: "um espaço para acolher pessoas de todas as denominações, crenças e não-crenças" (GIUMBELLI, 2013b, p. 36). A resposta da instituição católica veio de pronto pela grande imprensa, através de articulistas ligados à Igreja e pelo próprio Arcebispo Dadeus Grings. O argumento invoca de novo o aspecto "culturalista", ou seja, tradição católica de longo curso entranhada na cultura nacional. Associando a ideia do "espaço de espiritualidade" proposto pela direção do Hospital à "Nova Era/NewAge”, crença “oriental” sem nenhuma influência na nossa cultura, ao passo que o catolicismo era apresentado como religião enraizada na população (lembro aqui que o Rio Grande do Sul é um dos redutos do catolicismo no país), afirmavam não se tratar de direito à "liberdade religiosa", mas de "exclusão do próprio Sagrado" de sua missão de conforto aos doentes (GIUMBELLI, 2013b, p. 38).

Após muitas idas e vindas, sob a interveniência do Ministério Público Estadual, que procurou contemporizar a situação, decide-se manter a capela sob o controle da Igreja Católica e criar-se um outro centro ecumênico. A argumentação para o acordo firmada pelo Ministério Público apontava, por um lado, a necessidade de um espaço ecumênico, mas que resguardasse (também invocando o artigo 19 no parágrafo $5^{\circ}$ ) o "livre exercício do culto religioso" e a lei federal que assegura a "assistência religiosa" nos espaços hospitalares - relativizando a ideia da proibição de cultos e celebrações em prol da meditação e "recolhimento". A Recomendação do Ministério Público às partes em litígio parecia render-se às evidências, ela buscava assegurar um novo espaço ecumênico para as demais religiões, mas sem o confisco da "capela", visto que a Igreja Católica, na correlação de forças local, não se sentia obrigada a abrir mão dos seus 'direitos adquiridos' (GIUMBELLI, 2013b, p. 40). Neste caso, nota-se que a configuração resultante do 
embate entre forças laicistas e a Igreja Católica, numa região de forte presença católica, mas também de inserção de uma tradição jurisdicista e positivista, como é o Rio Grande do Sul, se estruturou numa repartição de ocupação entre Catolicismo na sua forma plena e o pluralismo religioso na sua forma ecumênica.

Por fim, ainda na direção da contenção do religioso no espaço público, aponto algumas intervenções de agentes públicos alegando valores laicos para coibir a presença religiosa, desta feita ocorrendo contra as religiões afro-brasileiras. Refiro-me a proposições surgidas na Assembléia Legislativa do Rio Grande do Sul e na Câmara Municipal de Porto Alegre, elencadas na pesquisa de Ari Oro, que reivindicando matéria de "higiene urbana" proibiam a colocação de animais mortos em logradouros públicos, tornando esta prática sujeita a multas; assim como outra que proibia sacrifício de animais invocando o Código de Defesa dos Animais. O autor aponta que a segunda proposta vinha de um deputado evangélico e associa estas medidas a "exemplos recentes de tentativa de discriminação das religiões afro-brasileiras" (ORO, 2011, p. 229) e tentativa de tolhimento à liberdade religiosa de reprodução ritualística desse meio religioso" (ORO, 2011, p. 229, nota 7). Interessante como aqui de novo, mesmo que possa ter como protagonista um deputado evangélico, não é - neste caso - o discurso religioso que envolve o projeto, mas questões "sanitárias" e "éticas", muitas vezes também arroladas por agentes civis laicos e "progressistas" contra o "obscurantismo" religioso.

Também é interessante notar que ambas as ações não prosperaram, sendo neutralizadas pela mobilização da comunidade afro-brasileira, que inclusive teve liminar impetrada julgada favoravelmente no Tribunal de Justiça do Estado (ORO, 2011, p. 229, nota 7). Isto em contraste com um padrão recorrente até então de resultados desfavoráveis no que tange a manifestações afro-brasileiras no campo jurídico contra o vilipêndio religioso praticado contra elas pelos neopentecostais, quadro que pode estar se modificando. 


\subsection{Ações contra a intolerância e vilipêndio religioso}

As religiões afro-brasileiras têm sido vítimas de perseguições históricas movidas desde às primeiras décadas do século XX por correntes higienistas, criminológicas e cientificistas (juízes, médicos, legisladores, jornalistas), pois consideravam a possessão e práticas curativas destas religiões como exercício ilegal de medicina e charlatanismo. Por isso, o judiciário e a polícia reprimiram estes cultos com invasões e fechamento de terreiros, assim como movendo processos criminais contra seus líderes e adeptos (ORO, 2011, p. 226; MARIANO, 2011, p. 246). Encerrado este ciclo de repressão pela conquista de certa legitimidade destas religiões enquanto expressão da "cultura nacional", estas, a partir dos anos 1980, são surpreendidas por novos ataques movidos por neopentecostais. São ataques desferidos contra as religiões afro-brasileiras tanto nos recintos fechados dos templos neopentecostais - onde representações de seus orixás e entidades "descem" e confessam serem diabos e seres do mal, sendo humilhados, exorcizados e expulsos -, quanto no espaço público através de suas redes de TV, rádio e imprensa, onde, por meio de testemunhos de ex-adeptos são "revelados" os "malefícios" praticados contra pessoas em nome das entidades diabólicas (ORO, 2007, p. 48-49; SILVA, 2007, p. 10-12).

Alguns exemplos destes casos de vilipêndio religioso foram a depredação de um centro de Umbanda no bairro do Catete no Rio, por 4 evangélicos; a ação do pastor Tupirani e de um membro da "Igreja Geração Jesus Cristo" de postar vídeos na internet insultuosos às religiões afro-brasileiras e à ordem legal protetora da liberdade religiosa, como o tema veiculado "Bíblia sim, Constituição não!"; assim como, a desqualificação da Lei Caó (que torna o racismo crime inafiançável) retratada como "Lei Caô" (gíria que significa mentira) (MIRANDA, 2010, p. 135). Também no Rio de Janeiro o Centro Umbandista Irmãos Frei da Luz foi apedrejado por freqüentadores de uma igreja da IURD vizinha no bairro da Abolição; uma adepta da Tenda Espírita Antônio de Angola foi mantida em cárcere 
rivado numa igreja evangélica de Duque de Caxias; em Salvador, uma casa de Candomblé no bairro Tancredo Neves foi invadida por membros da Igreja Internacional da Graça de Deus que atiraram sal grosso e enxofre nos participantes da celebração (SILVA, 2007, p. 12).

Uma literatura acadêmica debruçou-se sobre explicações para o que se constata como "inércia" e "falta de reação" das religiões afro-brasileiras a estes ataques neopentecostais. Alguns fatores explicativos para tal atitude seriam: o fato de serem religiões centradas no indivíduo, então muitos não se sentem pessoalmente atingidos pelos ataques; a estrutura da religião pulverizada em terreiros autônomos e concorrentes não propicia a união por uma causa comum; haveria um baixo grau de representatividade e capacidade de obtenção de apoio na sociedade nacional, particularmente no meio político, jurídico e religioso (ORO, 2007, p. 50-51). Isto diante das igrejas neopentecostais, com inserção na política através de suas bancadas nos parlamentos, com presença própria na mídia e possuidoras de uma eficiência jurídica através de uma equipe de advogados que, invocando o direito a "liberdade de culto", justifica e legitima as campanhas encetadas contra o Candomblé e Umbanda como portadoras de diabos e malefícios (ORO, 2007, p. 57).

No entanto, nos anos mais recentes, é possível notar uma crescente articulação organizacional das religiões afro-brasileiras e uma atuação pública destas em defesa de sua liberdade contra a intolerância religiosa. No Rio de Janeiro, em resposta à ação de traficantes ligados a neopentecostais que expulsaram casas de Candomblé e Umbanda do Morro do Dendê, Ilha do Governador, houve manifestação diante da ALERJ e em seguida a constituição da Comissão de Combate à Intolerância Religiosa (CCIR), em 2008, por iniciativa de religiosos de matriz afro-brasileira (MIRANDA, 2010, p. 131). No Rio Grande do Sul foi criada em 2002, na XI Semana da Consciência Negra, a Comissão de Defesa das Religiões Afro-Brasileiras (CDRAB), comissão esta composta por intelectuais e 
militantes do Movimento Negro e presidida por Mãe Norinha de Oxalá (ORO, 2007, p. 59). A Comissão do Rio de Janeiro já encaminhou demandas ao poder público como: a criação de um Plano Nacional de Combate à Intolerância Religiosa, a aplicação da lei que introduz nos currículos escolares do ensino público a disciplina "História e Cultura Afro-Brasileira", a criação de uma delegacia especializada em crimes étnicos e raciais (MIRANDA, 2010, p. 131-134) e foi uma das promotoras da "Caminhada em defesa da Liberdade Religiosa" que se realiza anualmente na orla da praia de Copacabana (MIRANDA, 2010, p. 132). A Comissão do Rio Grande do Sul atua em palestras nas escolas, organiza Seminários, participa de sessões públicas no parlamento, inclusive já tendo ido à Brasília na Câmara (ORO, 2007, p. 59). Esta comissão buscou ainda articulações mais amplas no terreno jurídico, da mídia e da política, nesta última conseguindo estimular candidaturas à vereança (em partidos como PT, PDT e PSB) de lideranças do meio religioso afro-brasileiro, no entanto, sem sucesso eleitoral (ORO, 2007, p. 62-65). A Comissão do Rio de Janeiro parece ter uma ação mais efetiva, pois, com o auxílio de um delegado de política e um promotor do Ministério Público Estadual, além dos seus membros efetivos, acolhe denúncias de supostas vítimas, encaminha e acompanha a queixa para registros de ocorrências em delegacias policiais, em seguida propondo, conforme o caso, denúncias no Ministério Público e formação de processos cíveis e ações por danos morais (MIRANDA, 2010, p. 132-135).

No entender da antropóloga Ana Paula Miranda, que realizou uma etnografia da atuação da Comissão, há uma preferência destes atores sociais pela noção de "tolerância” e não por "liberdade religiosa”, pois a primeira formulação espelha mais a realidade do conflito (e a maneira de como os atingidos devem defender-se), realidade esta que se expressa não numa relação de igualdade entre as partes, mas de assimetria (MIRANDA, 2010, p. 126-127). Também na interpretação de Oro não é apropriada a expressão de "guerra religiosa" para o tratamento do conflito, pois apenas um lado desfere ataques, cabendo ao outro encontrar expedientes de defesa, o que indicaria essa situação de assimetria (ORO, 2007, p. 53). No entanto, no prosseguimento do processo, segundo Miranda, estes 
são tipificados pelas autoridades como de "menor potencial ofensivo", como "calúnias", "injúrias" ou arquivados por falta de provas. Também nas Juntas de Conciliação as vítimas ouvem sugestões para desistir da ação para não enfrentar o desgaste de um processo longo. Enfim, tudo redunda em um sentimento meio generalizado entre os queixosos de terem seus problemas subestimados (MIRANDA, 2010, p. 136-139). Todavia, para a autora, a tentativa de dar visibilidade na esfera pública a estas agressões sofridas - tanto em processos judiciais quanto em atos públicos como a "Caminhada" - tem como objetivo explicitar uma característica central da intolerância religiosa contra as religiões afro-brasileiras que é a sua dissimulação (MIRANDA, 2010, p. 143).

Outras medidas judiciais contra o vilipêndio religioso sofrido pelas religiões afro-brasileiras em função de ataques da IURD foram acolhidas em instâncias judiciais. Temos o caso em 2003 na Bahia de uma denúncia feita pelo promotor do Ministério Público Estadual contra o programa televisivo da IURD na TV Itapoan e Cabrália, por estar denegrindo as tradições afro-brasileiras, apresentadas comoresponsáveis por "macumbas" que teriam levado indivíduos à morte (ORO, 2007, p. 55). E em 2004, também na Bahia, a sentença que obrigou a IURD a indenizar familiares de Mãe Gilda, ialorixá do Candomblé, que teve sua foto publicada na Folha Universal com comentários abjetos, e por conseqüência deste acontecimento entrou em depressão e veio a falecer (ORO, 2007, p. 56). Posteriormente, o dia de sua morte foi oficializado como "Dia de Combate à Intolerância Religiosa" por iniciativa de projeto de uma vereadora do PCdoB de Salvador (ORO, 2007, p. 56).

Uma outra situação de debates sobre intolerância religiosa - mas que poderia também ser enquadrada no cenário acerca das ações contra a presença de símbolos religiosos no espaço público - foi a da demanda que chegou à Comissão de Combate à Intolerância Religiosa (CCIR) do Rio de Janeiro, de uma professora afastada pela direção de seu cargo numa escola pública por estar trabalhando com 
o livro "Lendas de Exu" (que possuía o selo do MEC) na disciplina "disciplina "História e Cultura Afro-Brasileira" (MIRANDA, 2011, p. 8-10). Note-se que a professora no curso do processo se revelou sendo umbandista. Aqui a acusação à professora não vinha revestida de intolerância ao considerar "demoníacos" os conteúdos veiculados, mas o que foi acionado tanto pela diretora da escola quanto pelos pais de confissão evangélica, que se sentiram agredidos com o livro e as aulas, era que não se tratava de temática cultural da África, mas de "apologia religiosa", proselitismo religioso, incompatível com uma escola pública em um Estado laico (MIRANDA, 2011, p. 9-10). Interessante como neste caso o argumento da defesa da laicidade contra uma intromissão indevida do religioso no espaço laico veio de evangélicos geralmente praticantes do inverso.

Miranda propõe uma interpretação sobre o descompasso existente no país entre o que chama de "esfera pública", ou seja, o domínio institucional-legal, que legitimava o livro com o selo do MEC, enquanto fundamento conteudístico da disciplina "História e Cultura da África” e o “espaço público", onde a proporcionalidade de uma crença cristã (evangélico-católica) é predominante ditando o comportamento majoritário da sociedade e repercutindo de novo nas instituições (MIRANDA, 2011, p. 14). Aqui podemos encontrar um paralelo com os casos da manutenção da capela "católica” no Hospital das Clínicas de Porto Alegre, da manutenção dos crucifixos nos Tribunais, da expansão de aposição de Bíblias e de monumentos a ela nos logradouros públicos, da retirada dos direitos sexuais e reprodutivos dos textos de leis e planos pelo Governo Federal e do ensino religioso confessional; tudo dentro da correlação de forças com respeito à supremacia cristã na "cultura nacional”. Ainda que, com direito ao contestatório e vitórias parciais de forças laicas e inter-religiosas. 


\section{Conclusão}

Ainda que alguns importantes cientistas sociais mantenham um tom mais radical quando se referem ao fato de que "a laicidade não constitui um valor central na República" (ORO, 2011, p. 229) ou que a "laicidade não dispõe de força normativa e ascendência cultural” (MARIANO, 2011, p. 254), o consenso estabelecido entre estudiosos do tema parece ser o de que no Brasil a separação entre Estado e Igreja nunca resultou na saída da religião da vida pública. E, portanto, que o termo "laicidade" no país parece funcionar mais como uma "referência" utilizada para tratar das relações entre religiões e Estado, referência esta sempre valorizada e adaptada aos interesses de cada um destes segmentos sociais, civil ou religioso.

Emerson Giumbelli ao refletir sobre as “configurações” por onde podemos conceber a laicidade, entende que nelas se "mobiliza uma diversidade de manifestações" (GIUMBELLI, 2013b, p. 45). Ou seja, a(s) laicidade(s) são de diversas formas. Em seguida, ele afirma que "caracterizá-las é nossa tarefa”, reconhecendo que elas podem tanto "representar soluções" quanto "impasses" (GIUMBELLI, 2013b, p. 45).

Foi essa perspectiva que me estimulou a compreender e comparar casos da "laicidade à brasileira" na forma de um mosaico de cenários: configurações ou arenas em descompasso entre si, mas que também podem ser articuladas num arranjo, ainda que em estado de tensão. Interessante notar que em todas estas arenas prevalece de forma recorrente e contínua a consigna da laicidade, que é sempre acionada por todos os contendores, sejam estes do campo religioso ou laico nas disputas que travam entre si, não sendo a laicidade "nunca combatida ou negada de forma explícita” (RANQUETAT JR, 2010, p. 187). Daí aquela afirmação dos bispos católicos de que “o Estado é laico, mas não é ateu!” (MIRANDA, 2013, p 69), preservando a primeira assertiva e desqualificando o que para eles significava 
a injustificada supressão da religião da vida pública. Tanto os que defendem a manutenção dos símbolos religiosos em espaço estatal quanto os que sustentam sua retirada, ambos estão invocando o princípio da laicidade (GIUMBELLI, 2012, p. 57). Também nos casos de proposições díspares para o Ensino Religioso, ou como parte da cultura nacional ou de caráter confessional, "em nenhuma das proposições apresentadas se observa uma recusa da noção de laicidade" (GIUMBELLI, 2004, p. 56). De fato, a primeira proposição do sociólogo José Casanova para o regime de secularização, que é a diferenciação das esferas seculares de instituições religiosas, não impede a emergência de grupos religiosos de pressão para disputar espaço com grupos seculares na esfera pública (CASANOVA, 2006, p. 7-22). Afinal, Miranda já havia intuído que, pelo "fato de um Estado proclamar-se laico, não significa o fim dos conflitos entre Estado e religião" (MIRANDA, 2010, p. 125).

Portanto, como estas concepções de laicidade são sempre móveis e situadas, os quatro cenários - arenas ou configurações - que propus como instrumentos de análise podem ser embaralhados e permutados uns por outros: as ações religiosas que inibem políticas de direitos humanos revelam também a existência e visibilidade dessas iniciativas laicas; as ações para retirada de símbolos religiosos no espaço público não logram êxito com a permanência destes símbolos; a ocupação do cenário público por imagens religiosas implica também competição entre católicos e evangélicos, onde os evangélicos se unem aos laicos para contestar a ocupação católica, para, em seguida, estabelecerem com os católicos um acordo de repartição deste espaço público; a presença pública das religiões afro-brasileiras podem ser apoiadas enquanto direito à liberdade religiosa ou contestada por argumentos higienistas ou de "proteção dos animais" que provém do campo laico . Enfim, o que pode ser retração do religioso, por outro ângulo, pode significar expansão e vice-versa. 
Desta maneira, mobilizações e ações jurídico-políticas de procedências religiosas ou laicas - ou ainda de alianças de determinadas religiões com determinados laicos - dentro da ordem democrática, todas estas podem invocar os direitos (humanos, sexuais ou à vida) de acordo com suas concepções de mundo, buscando sua aprovação ou supressão em termos legais, para moldar, segundo esses critérios o cenário da res-publica.

\section{REFERÊNCIAS}

ASAD, Talal. Formations of the secular. Stanford: Stanford University Press, 2003.

BELLAH, Robert N. Civil Religion in America. In: BELLAH, Robert N. Beyond Belief: Essays on Religion in a Post-Tradicional World. Berkeley, Los Angeles, London: University of California Presss, 1987. p.168-189.

CASANOVA, José. Public religions in a modern world. Chicago: University Chicago Press, 1994.

CASANOVA, José. Rethinking Secularization: a global comparative perspective.The Hedgehog Review, Charlottesville, v. 8, n. 1/2, p. 07-22, 2006.

EADE, J.; SALLNOW, M.J. Contesting the sacred: the anthropology of Christian pilgrimage. London, New York: Routledge, 1991.

GIUMBELLI, Emerson. Religião, estado, modernidade: notas a propósito de fatos provisórios. Estudos Avançados, São Paulo, v. 18, n. 52, p. 47-52, 2004.

GIUMBELLI, Emerson. Crucifixos em recintos estatais e monumento do Cristo Redentor: distintas relações entre símbolos religiosos e espaço público. In: ORO, Ari et al. A Religião no Espaço Público: atores e objetos. São Paulo: Terceiro Nome, 2012. p. 4560.

GIUMBELLI, Emerson. Para estudar a laicidade, procure o religioso. In: BÉLIVEAU, Verónica Giménez; GIUMBELLI, Emerson (Org.). Religión, Cultura e política en las Sociedades del siglo XXI. Buenos Aires: Biblos, 2013a. p. 43-68.

GIUMBELLI, Emerson. O que é um ambiente laico? Espaços (inter) religiosos em instituições públicas. Cultura y Religión, Iquique, v. 7, n. 2, p.32-47, 2013b.

MACHADO, Maria das Dores Campos; MARIZ Cecília. Mudanças Recentes no campo religioso brasileiro. (mimeo), Rio de Janeiro, UERJ/UFFRJ, 1998. 
MARIANO, Ricardo. Laicidade à brasileira: católicos, pentecostais e laicos em disputa na esfera pública. Civitas, Porto Alegre, v. 11, n. 2, p.238-258, 2011.

MARIANO, Ricardo; ORO, Ari Pedro. Eleições 2010: Religião e Política no Rio Grande do Sul e no Brasil. Debates do NER, Porto Alegre, v. 2, n. 18, p. 11-38, 2010.

MARIZ, Cecília. Algumas reflexões sobre religião e luta pela cidadania. In: BURITY, Joanildo; ANDRADE, Péricles (Org.). Religião e Cidadania. São Cristovão: Editora UFS, Recife: Fundação Joaquim Nabuco, 2011.

MIRANDA, Ana Paula Mendes. Entre o privado e o público: considerações sobre a (in) criminação da intolerância religiosa no Rio de Janeiro. Anuário Antropológico 2009/2, Brasília, UnB, 2010, p.125-152.

MIRANDA, Ana Paula Mendes.A intolerância religiosa e o ensino religioso confessional obrigatório em escolas públicas no Rio de Janeiro. XI Congresso Luso Afro Brasileiro de Ciências Sociais. o7 a 10 de agosto de 2011. UFBA|. Disponível em: <http://www.xiconlab.eventos.dype.com.br/resources/anais/3/1307634312_ARQUIVO_a intoleranciareligiosaeoensinoconfessionalobrigatorioemescolaspublicasnoRiodeJaneiro.pd f>. Acesso em: 5 abr. 2017.

MIRANDA, Júlia. Estado laico no Brasil: entre sofismas e ambigüidades. Cultura y Religión, Iquique, v. 7, n. 2, p. 69-85, 2013.

ORO, Ari Pedro. Avanço pentecostal e reação católica. Petrópolis: Vozes, 1996.

ORO, Ari Pedro. Intolerância Religiosa Iurdiana e Reações Afro no Rio Grande do Sul. In: SILVA, Wagner Gonçalves da (Org.) Intolerância Religiosa: impactos do neopentecostalsimo no campo religioso afro-brasileiro. São Paulo: EdUSP, 2007. p. 29-70.

ORO, Ari Pedro. A laicidade no Brasil e no Ocidente. Algumas considerações. Civitas, Porto Alegre, v. 11, n. 2, p.221-237, 2011.

PORTIER, Philippe. Introduction - Une Église Mosaïque. Le mouvement catholique à l'épreuve de la pluralité: enquêtes autour d'une militance eclatée. Rennes: Presses Universitaires de Rennes, 2002.

PORTIER, Philippe. L'Amérique et la France face à 'l'esprit de religion' : retour sur une comparaison tocuevillienne. Social Compass, Louvain, v. 57, n. 2, p. 180-193, 2010.

PORTIER, Philippe. A regulação estatal da crença nos países da Europa Ocidental. Religião \& Sociedade, Rio de Janeiro, v. 31, n. 2, p. 11-28, 2011.

PORTIER, Philippe ; LAGRÉE, Jacqueline. La modernité contre la religion? Pour une nouvelle approche de la laïcité. Rennes : Presses Universitaires de Rennes, 2010. 
RANQUETAT JR, César Alberto. O Acordo entre o governo brasileiro e a Santa Sé e a Lei Geral das Religiões: Estado, Religião e Política em debate. Debates do NER, v. 2, n. 18, p. 173-191, 2010.

RANQUETAT JR, César Alberto. A presença da Bíblia e do crucifixo em espaços públicos no Brasil: religião, cultura e nação. In:ORO, Ari Pedro et al. A Religião no Espaço Público: atores e objetos, São Paulo: Terceiro Nome, 2012. p. 61-79.

RODRIGUES, Michelle G. Da invisibilidade à visibilidade da Jurema: a religião como potencialidade política. Tese de doutorado. Programa de Pós-Graduação em Antropologia da Universidade Federal de Pernambuco. Recife, 2014.

SANSI, Roger. Fetiches e monumentos: arte pública, iconoclastia e agência no caso dos 'orixás' do dique de Itororó. Religião \& Sociedade, Rio de Janeiro, v. 25, n. 2, p. 62-81, 2005 .

SILVA, Wagner Gonçalves. Prefácio ou Notícias de uma Guerra Nada Particular: Os Ataques Neopentecostais às Religiões Afro-brasileiras e os Símbolos da Herança Africana no Brasil. In: SILVA, Wagner Gonçalves da (Org.). Intolerância Religiosa: impactos do neopentecostalsimo no campo religioso afro-brasileiro. São Paulo: EdUSP, 2007. p. 9-28.

WILLAIME, Jean-Paul. Pluralité religieuse et citoyenneté en France et en Allemagne. In : MILOT, Micheline ; PORTIER, Philippe; WILLAIME, Jean-Paul (Ed.). Pluralisme religieux et citoyenneté. Rennes: Presses Universtaires de Rennes, 2010. p. 139-151.

WILLAIME, Jean-Paul. Les évolutions en Europe vers une laïcité de reconnaissance et de dialogue. Symposium Internacional sur l'interculturalisme Dialogue Québec-Europe. Montreal, 27-27, mai 2011. 